\title{
Where There's a Will There's a Way?: Survey of Academic Librarian Attitudes about Open Access
}

\author{
Kristi L. Palmer, Emily Dill, and Charlene Christie
}

\begin{abstract}
Academic libraries are becoming increasingly involved in scholarly communication through work with institutional repositories and other open access models. While academic librarians are being encouraged to promote these new models, their opinions about open access have not been documented. This article reports on the results of a national survey conducted in the summer of 2006 of academic librarians' attitudes toward open access principles and related behaviors. While attitude responses were largely positive, there were differences in levels of support related to respondents' job descriptions and funding of open access activities. Surveyed librarians appear to be more comfortable with tasks that translate traditionally held responsibilities, such as educating others, to the open access environment. Most significant is the discrepancy between stated support of library involvement in open access initiatives and significantly lacking action toward this end. The results offer insight into how open access proponents may better focus their advocacy efforts.
\end{abstract}

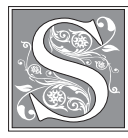

ince the advent of scholarly journals in the mid-seventeenth century, scholars have been seeking better ways to disseminate their intellectual output (for an extensive history of scholarly communication, including the role of libraries, see In Oldenburg's Long Shadow: Librarians, Research Scientists, Publishers, and the Control of Scientific Publishing by Jean-Claude Guédon). ${ }^{1}$ Scholars want to share their ideas with others for a variety of reasons - to establish their reputations, to help solve problems, or to build upon the knowledge base in their fields, to name but a few. Finding the fastest way to communicate their thoughts with the widest possible audience has been a challenge for scholars since the advent of the first journals. Technological and cultural developments, especially over the past 40 years, have made dissemination of this work increasingly efficient. The innovation of the open access movement is perhaps the most likely method to make a fundamental change in how information is shared. The groundswell of interest in open access issues from such a wide variety of sectors and geographic locations shows the seriousness of this movement

Kristi L. Palmer is Assistant Librarian at Indiana University-Purdue University Indianapolis; e-mail: klpalmer@iupui.edu. Emily Dill is Assistant Librarian at Indiana University-Purdue University Columbus; e-mail: eadill@iupuc.edu. Charlene Christie is Assistant Professor of Psychology at SUNY College at Oneonta; e-mail: christcs@oneonta.edu. 
(for a detailed history of open access, see Peter Suber's "Timeline of Open Access Movement"). ${ }^{2}$

There are a variety of definitions of open access; each reflects the concerns of the person or group defining the term. The three most commonly used are referred to as the Budapest, Bethesda, ${ }^{3}$ and Berlin ${ }^{4}$ definitions. While the definitions all include three major characteristics: 1. Free, 2. In digital form, and 3. Able to be used by others, each has a nuanced interpretation of the concept. The usageoriented characteristic requires lengthy explanation, as exemplified by the Budapest Open Access Initiative definition: "[open access to literature means it is] freely available on the public [I]nternet, permitting any users to read, download, copy, distribute, print, search, or link to the full texts of these articles, crawl them for indexing, pass them as data to software, or use them for any other lawful purpose, without financial, legal, or technical barriers other than those inseparable from gaining access to the [I]nternet itself. The only constraint on reproduction and distribution, and the only role for copyright in this domain, should be to give authors control over the integrity of their work and the right to be properly acknowledged and cited." ${ }^{5}$

To avoid an overly complex and lengthy survey introduction, a succinct definition of open access, excluding any language regarding usage, was employed for this research. Open access was defined to survey participants as "scholarship that is available online free of charge." However it is defined, open access is a contentious topic among scholars, publishers, librarians, government agencies, and professional societies. Each of these groups brings different needs and concerns to the evolving conversation about scholarly communication, which thereby dictates the groups' priorities with regard to open access.

As an example of group-defined priorities, a study by Nancy Fried Foster and Susan Gibbons, which examines how scholars communicate, indicates that faculty are interested in what technology can do to enhance their scholarly communication, as long as this process does not add to their workload. ${ }^{6}$ Other concerns, such as rising journal costs and control of intellectual property, do not necessarily fall under the primary concerns of faculty, because they do not affect their day-to-day work. For-profit journal publishers are likely most interested in how changes in scholarly communication will affect their revenue, with profit gain as their primary goal. Some professional society publishers have resisted open access initiatives because of the strong connection between their publication revenues and the ability to support their other societal activities. When considering how open access might be regarded in the library profession, the view changes once again. Librarians may consider open access to be the solution to their dwindling journal budgets, though open access scholar Stevan Harnard suggests this is "irrelevant" and should not be the driving force behind open access advocacy. ${ }^{7}$ Librarians may also be wary of a scholarly communication system that, as described by Krista D. Schmidt, Pongracz Sennyey, and Timothy V. Carstens, will fundamentally change the way libraries are used in that patrons will no longer need to physically or virtually visit the library. ${ }^{8}$ Any successful innovations in open access will have to consider the needs and roles of all of these differently motivated yet interdependent stakeholders.

For libraries, open access offers a variety of new opportunities and challenges. In the long-term, open access may help shrinking materials budgets by mitigating costs for resource purchase and access. It may also reduce some of the headaches involved in negotiating electronic journal and database licenses. Regardless of these potential benefits, there are also significant challenges. Librarians must confront a demand for new skill sets and roles. Librarians' concept of preservation will need to be reconfigured to the digital environment. Library administrators will 
need to make tough decisions regarding the reallocation of resources. Sara Fine describes the domino effect of change that major shifts of this nature have historically brought to libraries in this way: "Reporting lines change, work groups change, work styles change, friendships change, the physical environment may change, time structures change, and so it goes. And yet, most libraries will go through major personnel restructuring at the same time they are implementing major technological or procedural changes. No wonder people resist." ${ }^{\prime 9}$

Compounding all of these possible opportunities and challenges is the unknowable future of open access. It is therefore hardly surprising, given this chaotic environment, that opinions about the desirability of open access differ from librarian to librarian. Many professional associations, including the Association of College and Research Libraries, identify open access as a main concern for the profession. ${ }^{10}$ What is unknown is how librarians actually feel about open access and, specifically, how librarians feel about their profession's involvement in promoting open access. Knowing how librarians feel about open access, in addition to how many libraries are involved in open access, in what form and to what extent, will help the profession move toward a more purposeful and productive interaction with the open access movement. This study hopes to address these knowledge gaps.

\section{Literature Review}

The growing body of literature available on scholarly communication issues comes from a diverse group of scholars representing equally diverse perspectives. This literature review provided insight into specific facets of the authors' survey, such as librarian involvement in educating others about open access, budgetary issues related to open access, and opinions about open access from both the public and researchers. Some quantitative research was located concerning library involvement in open access work; however, none was found examining the overall opinions of librarians regarding open access. Librarian Charles W. Bailey, Jr.'s “Scholarly Electronic Publishing Bibliography" offers a comprehensive view of the publication record on scholarly communication topics, the majority of which focus on best practices, predictions, and opinion papers, as opposed to statistical analyses. ${ }^{11}$ An open access scholar himself, Bailey's 2007 article, "Open Access and Libraries," echoes opinions presented in the report to follow. Specifically, Bailey voices that "libraries have been somewhat cautious in their embrace of open access, uncertain about its...ultimate impact on their budget and operations," and that "open access does not require that libraries do anything for it to exist." 12

Suzie Allard, Thura R. Mack, and Melanie Feltner-Reichert's 2000-2004 content analysis of professional literature found that "nearly one-third of the articles did not mention libraries or librarians in their discussions of [institutional repositories]. This suggests that librarian involvement is not seen as a defining feature of [institutional repositories], by everyone involved in the early stages of [institutional repository] development." ${ }^{13}$ However, both the report to follow and a 2005 study conducted by the Coalition for Networked Information (CNI), which reports on the number of libraries involved with institutional repositories, indicate a growing involvement of libraries in repository work. Of the 132 higher education institutions that completed the CNI survey sent to 205 institutions, 40 percent were operating institutional repositories. ${ }^{14}$

The "JISC/OSI Journal Authors Survey Report," prepared by Alma Swan and Sheridan Brown, describes the experiences of authors who have published via open access and those who have not. Among the discoveries of this report is the following: "Awareness of the concept of open access amongst those who had not taken this publishing route was quite 
high: almost two-thirds of respondents were familiar with the open access concept. Only around a quarter of authors in this group had been made aware of open access initiatives by their institution. The proportion of open access author respondents whose institution had drawn their attention to such outlets was higher, at $42 \%$. The same pattern was seen when authors were asked whether they were aware of any initiatives in their own country to promote open access." 15 The JISC/OSI study adds a much-needed piece to the open access puzzle and alludes to the successes of open access education campaigns (potentially led by librarians), but it does not address the opinions of academic librarians who are often managing the open access tools. Another study, by Howard Carter, Carolyn A. Snyder, and Andrea Imre, that focuses on the publishing practices of librarians with faculty status, revealed that only 12 percent of survey respondents had self-archived their publications. ${ }^{16}$

Again touching on librarians as educators, The Association of Research Libraries SPEC Kit 299: Scholarly Communication Education Initiatives designed by Kathleen A. Newman, Deborah D. Blecic, and Kimberly L. Armstrong reports on a 2007 survey of academic libraries and specifically addresses library involvement in educating others (including faculty, university administration, other librarians, and students) on scholarly communication issues, including open access. "Seventythree libraries (59\%) responded to the survey. Of those, 55 (75\%) indicated that the library has engaged in educational activities on scholarly communication issues; 13 (18\%) have not but indicated that planning is underway. Only three libraries indicated that they had not engaged in this activity; another two responded that this is the responsibility of another, nonlibrary unit of the institution."17

A 2004-2005 study by Leslie Carr and Stevan Harnad speaks to one of the significant issues discovered in the report to follow: funding open access measures in libraries. Carr and Harnard measured the amount of time and effort (and, tangentially, economic resources) it takes for researchers to deposit an item in an open access archive. Their research found that self-archiving only required about ten minutes of work per paper. ${ }^{18}$ Studies such as these serve to break down beliefs that open access initiatives will add significantly to the workloads (and possibly budgets) of university departments and libraries.

An attitude-based survey, Faculty Attitudes and Behaviors Regarding Scholarly Communication: Survey Findings from the University of California, prepared by the University of California Office of Scholarly Communication in November 2006, details faculty opinions about scholarly communication. The University of California survey results are detailed later in this paper, as they provide an interesting comparison between faculty and librarian attitudes regarding open access. ${ }^{19}$ Finally, a 2006 public opinion Harris Poll on access to federally funded health-related research revealed that " $82 \%$ of adults say they strongly $(57 \%)$ or somewhat $(25 \%)$ agree that if tax dollars pay for scientific research, people should have free access to the results of the research on the Internet." ${ }^{20}$ While these and other studies explore attitudes of various groups in relation to some aspect of open access, the authors did not find comprehensive, quantitative research regarding librarian attitudes toward the concepts of open access or their profession's involvement in open access work.

\section{Methods}

To begin to address this gap in knowledge, the authors created an anonymous three-part survey containing a total of 37 questions. Part I (survey statements 1-21) assessed respondents" "personal opinions about academic libraries' involvement in scholarly communication and open access issues." The statements used a seven-point Likert scale with responses ranging from strongly disagree to strongly 
agree. The reliability of our measure was assessed using Cronbach's alpha, a statistical index of internal consistency. Cronbach's coefficient alpha assesses the average inter-item correlations among the individual items comprising an overall measure of a variable. As with other correlation coefficients, values closer to 1.0 indicate stronger relationships (in this case, a higher degree of internal consistency). Since reliability analyses revealed that these 21 items formed a cohesive measure of overall attitudes toward open access issues (Cronbach's alpha $=.91$ ), the authors used this set to create an overall measure of attitudes to use in subsequent analyses.

Part II (survey statements 22-29) used a five-point Likert scale to assess the frequency of "certain behaviors related to open access," with possible responses ranging from never to every day. Reliability analyses revealed that these eight items formed a cohesive measure of open access-related behaviors (Cronbach's alpha $=.89$ ). Thus, the authors created an overall index of behavior to use in the subsequent analyses. Part III (survey statements 30-37) encompassed demographic questions, including basic information such as age, gender, and the number of years a respondent has been a librarian, as well as relevant job characteristics such as primary position type in the library and whether the respondent was personally involved in the management of open access projects. The survey was created using the Zoomerang survey tool and was accessed by respondents via the Web.

While open access certainly has an impact on nonacademic libraries and librarians, the focus of this study is on academic libraries. Unless stated otherwise, when the terms "libraries" and "librarians" are used, the reader should assume them to mean "academic libraries" or "academic librarians." The survey instrument was pretested with a cohort of librarians, and the authors made some minor survey changes based on the feedback received. While exploring participant recruitment strategies, the authors considered several methods including purchasing a list of librarian names from the American Library Association or soliciting responses through various listservs. The authors ultimately felt that limiting the participants to those who belonged to a certain association or listserv would not provide a representative sample.

Ultimately the authors chose to randomly select a subset of libraries from the institutions identified in the $\mathrm{Na}$ tional Center for Education Statistics 2002 Academic Library Survey (NCES-ALS), which totaled 3,887 academic colleges and

\begin{tabular}{|c|c|c|c|c|c|}
\hline \multicolumn{6}{|c|}{$\begin{array}{c}\text { TABLE } 1 \\
\text { Libraries by Highest Level of Degree Granted as Identified on NCES-ALS } \\
\text { Survey* }\end{array}$} \\
\hline & Associate & Baccalaureate & Master's & Doctoral & Other \\
\hline Percentage (number) of libraries & $\begin{array}{l}39.4 \% \\
(1531)\end{array}$ & $\begin{array}{c}18.2 \% \\
(709)\end{array}$ & $\begin{array}{c}25.3 \% \\
(982)\end{array}$ & $\begin{array}{c}16.2 \% \\
(631)\end{array}$ & $\begin{array}{c}0.9 \% \\
(34)\end{array}$ \\
\hline $\begin{array}{l}\text { Percentage (number) of libraries } \\
\text { randomly selected for open access } \\
\text { survey }\end{array}$ & $\begin{array}{c}40.7 \% \\
(143)\end{array}$ & $\begin{array}{c}14.8 \% \\
(52)\end{array}$ & $\begin{array}{c}25.9 \% \\
(91)\end{array}$ & $\begin{array}{c}17.9 \% \\
(63)\end{array}$ & $\begin{array}{c}0.6 \% \\
(2)\end{array}$ \\
\hline $\begin{array}{l}\text { Percentage (number) of libraries } \\
\text { to which open access survey was } \\
\text { sent }\end{array}$ & $\begin{array}{c}30.5 \% \\
(72)\end{array}$ & $\begin{array}{c}16.1 \% \\
(38)\end{array}$ & $\begin{array}{c}30.9 \% \\
(73)\end{array}$ & $\begin{array}{c}21.6 \% \\
(51)\end{array}$ & $\begin{array}{c}0.8 \% \\
(2)\end{array}$ \\
\hline \multicolumn{6}{|c|}{$\begin{array}{l}\text { *NCES-ALS categories were collapsed to better reflect the highest degree granted categories used } \\
\text { in the open access survey, Question 34. See Documentation for the Academic Library Survey (ALS) } \\
\text { Data File: Fiscal Year 2002, Appendix H, p. H-15 for detailed NCES-ALS highest degree granted } \\
\text { categories, available at: http://nces.ed.gov/pubs2006/2006308.pdf. }\end{array}$} \\
\hline
\end{tabular}


universities. ${ }^{21}$ Using a statistical analysis formula developed by measurement specialists Robert V. Krejcie and Daryle W. Morgan as a means of determining appropriate sample size, the authors randomly selected 351 institutions (of which 236 supplied sufficient contact information to include in the survey)from the 3,887 total and sent an e-mail to all librarians from those institutions asking them to participate in the survey. ${ }^{22}$

The authors recognize that a more representative, yet also more time-consuming, sample could be gathered by creating a database of all of the librarians listed on all 3,887 academic library sites, then using the Krejcie and Morgan formula to randomly select the appropriate subset from this larger contingency. The authors also recognize that the selection guidelines potentially exclude certain types of libraries at a higher rate than others, such as smaller libraries that cannot support Web site development. Table 1 and figure 1 provide insight into the types of libraries that were randomly selected for surveying and respondents' self-reported library types. ${ }^{23}$ In total, 1,517 invitations to participate in the survey were sent out, and 261 surveys were completed, making the response rate $17 \%$.

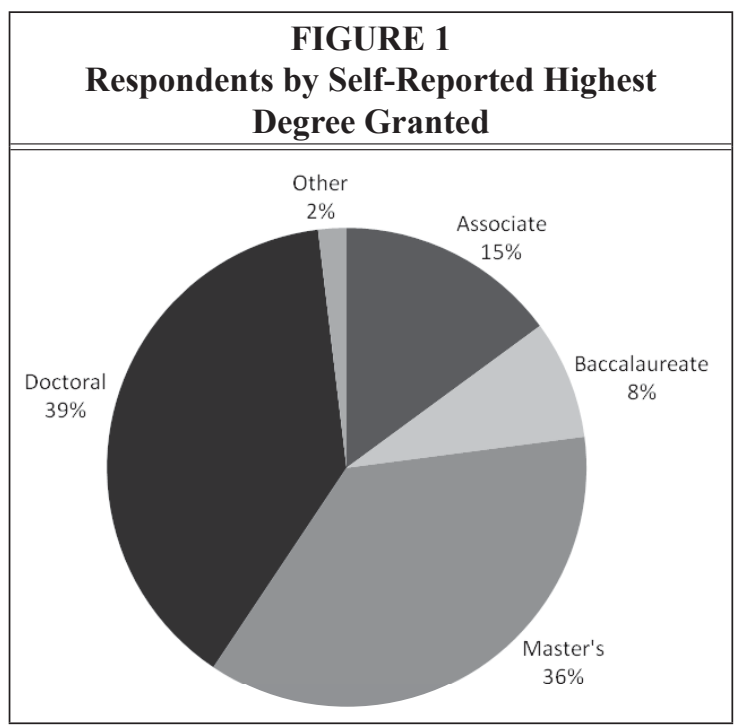

\section{Findings and Analysis \\ General Relationship between Attitudes and Behaviors}

A series of quantitative statistical analyses were conducted to examine the relationship between respondents' demographic characteristics, attitudes towards open access, and open access-related behaviors. The first analysis was a simple Pearson correlation, used to determine whether respondents' attitudes (reported in survey items 1-21; see Appendix A for full survey) were significantly associated with their open access-related behaviors (reported in survey items 22-29). Overall, the attitudes reported by respondents were quite positive, with the average attitude score being well over the neutral midpoint $(M=5.42, S D=.753)$. (See table 2.) The open access-related behaviors were not as popular, with the average response indicating that respondents are engaging in these behaviors several times a year $(M=1.85, S D=.565)$. (See table 3.) More directly stated, while librarians believe their profession should be supporting open access not only in concept but in action, few respondents were actually taking action toward open access's ends. Despite this disparity in overall positivity and frequency, the correlation between open access attitudes and behaviors was statistically significant $(r=.31, p<.001)$, showing that more positive attitudes toward open access issues were associated with greater frequency of open access-related behaviors.

\section{Impact of Specific Job Characteristics on Attitudes and Behaviors}

As librarians who added the development, management, and promotion of an open access institutional repository to their already hectic workflow, the authors were interested in knowing if people who were personally involved in 


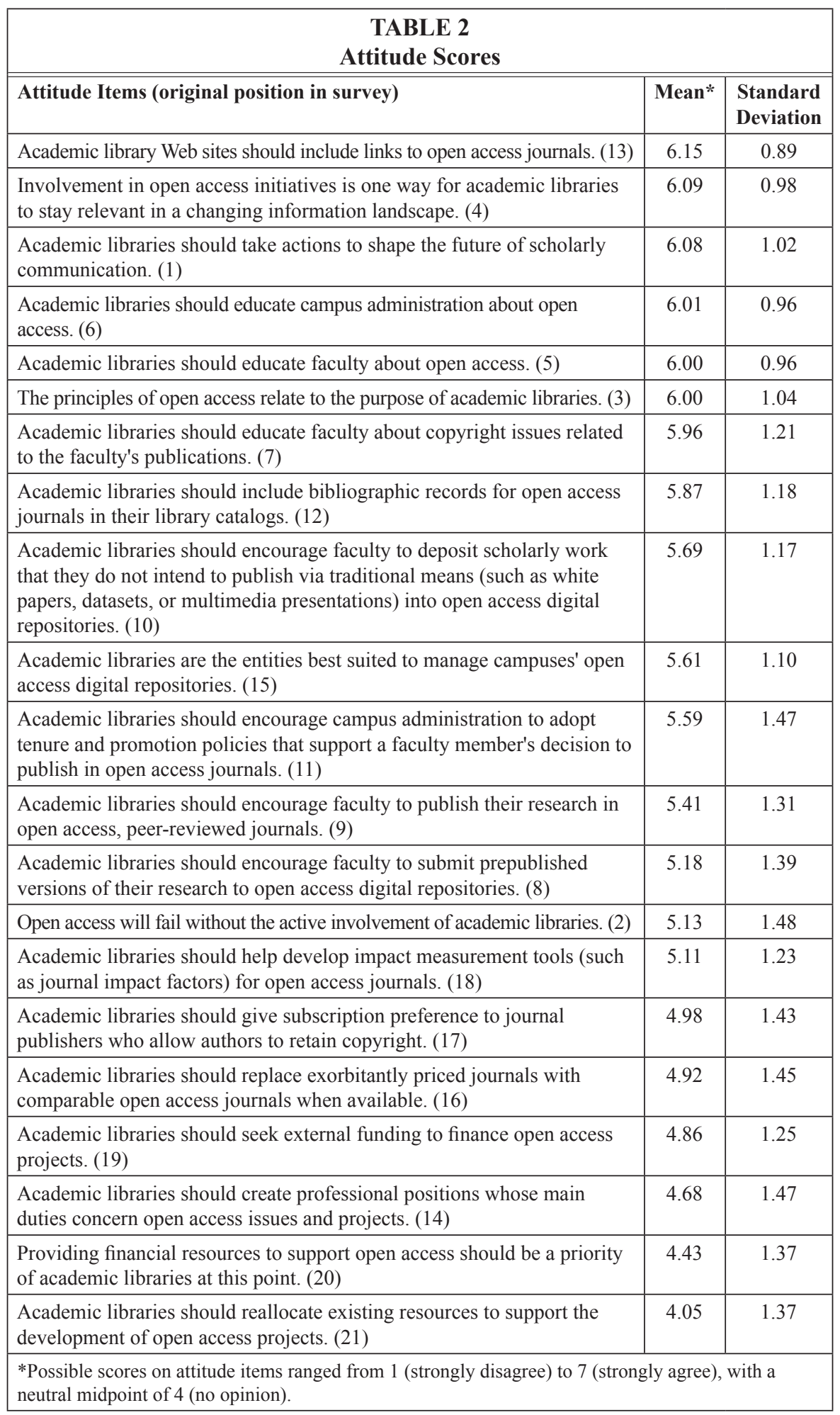




\begin{tabular}{|l|c|c|}
\hline \multicolumn{3}{|c|}{ TABLE 3 } \\
\hline \multicolumn{2}{|c|}{ Performed Behavior Scores } \\
\hline \hline Behavior Items (original position in survey) & Mean* & $\begin{array}{c}\text { Standard } \\
\text { Deviation }\end{array}$ \\
\hline $\begin{array}{l}\text { On average, I read professional literature that discusses open access. } \\
(23)\end{array}$ & 2.39 & 0.80 \\
\hline $\begin{array}{l}\text { On average, I monitor listservs, Web sites, and/or blogs that discuss } \\
\text { open access. (22) }\end{array}$ & 2.28 & 1.15 \\
\hline On average, I discuss open access with librarians at my campus. (25) & 2.16 & 0.80 \\
\hline $\begin{array}{l}\text { On average, I discuss open access with administrators at my library. } \\
\text { (28) }\end{array}$ & 1.77 & 0.74 \\
\hline $\begin{array}{l}\text { On average, I discuss open access with nonlibrarian, academic } \\
\text { professionals at my campus. (26) }\end{array}$ & 1.72 & 0.77 \\
\hline $\begin{array}{l}\text { On average, I discuss open access with librarians at campuses } \\
\text { outside my own. (24) }\end{array}$ & 1.72 & 0.64 \\
\hline $\begin{array}{l}\text { On average, I discuss open access with nonlibrarian, academic } \\
\text { professionals at campuses outside my own. (27) }\end{array}$ & 1.37 & 0.58 \\
\hline $\begin{array}{l}\text { On average, I discuss open access with nonlibrary administrators at } \\
\text { my campus. (29) }\end{array}$ & 1.33 & 0.55 \\
\hline $\begin{array}{l}\text { *Possible responses for behavior items included 1 (never), 2 (several times a year), } \\
\text { month), 4 (several times a week), and 5 (every day). }\end{array}$ & \\
\hline
\end{tabular}

managing different open access projects had higher opinion scores regarding open access issues and projects. A one-way ANOVA was used to examine the mean attitude scores for respondents personally involved in the management of various open access projects. The resulting F-test revealed a statistically significant main effect of being involved in managing educational campaigns $(F(1,256)=8.41$, $p<.01)$, with those individuals having significantly higher open access attitudes $(M$ $=5.96$ ). The other categories of personal involvement examined, managing a repository or open access journal, showed no significant differences in open access attitudes.

An additional ANOVA analysis was used to determine whether personal involvement in the management of open access projects had an impact on the frequency of open access-related behaviors. The resulting F-test again revealed a statistically significant main effect of being involved in the management of education campaigns $(F(1,256)=45.13$, $p<.001)$, with those individuals reporting more frequent open access-related communication behaviors $(M=2.72)$. While managing an institutional repository or open access journal does not affect attitude or frequency of open access-related communication, individuals involved in educating others about open access are more likely to not only support the concepts of open access but to also more frequently read or communicate with others about open access. A similar correlation was found when respondents were asked about their institutions' involvement in education campaigns.

\section{Impact of Institutional Involvement in Open Access on Attitudes and Behaviors}

Since it was assumed that not all respondents would be personally involved in open access projects, the survey also assessed whether each respondent's institution was involved in managing any open access projects. Subsequent ANOVA tests revealed a similar pattern when examining the impact of institutional 
involvement in open access projects on respondents' open access-related attitudes and behaviors. Specifically, there was a statistically significant main effect of institutional involvement in educational campaigns $(F(1,256)=4.31, p<.05)$, with people working at institutions that were managing open access educational campaigns reporting more positive attitudes toward open access $(M=5.63)$.

A similar finding resulted from the ANOVA analysis examining the impact of institutional involvement in open access projects on respondents' open accessrelated behaviors. The F-test revealed a statistically significant main effect of institutional involvement in educational campaigns $(F(1,256)=7.64, p<.01)$, with people working at institutions that were managing educational campaigns reporting more frequent open access-related behaviors $(M=2.12)$.

\section{How Demographic Characteristics Relate to Open Access Attitudes and Behaviors}

Also of interest was how attitude and behavior related to various librarian characteristics. The authors were particularly interested in whether librarians new to the field were more apt to be involved in open access projects. There was no relationship between open access attitudes and the number of years the respondents had been librarians $(r$ $=.057$, n.s.), nor was there a significant relationship between number of years as a librarian and frequency of open access-related behaviors $(r=.076$, n.s.). However, librarians who were personally involved in managing digital repositories had been librarians for fewer years $(M=10.45$ years $)$ than people not involved in managing digital repositories $(M=17.69$ years $), F(1,256)=7.11$, $p<.01)$. The same degree of difference was not true for those managing open access journals or open access education campaigns. This finding led the authors to consider two hypotheses:

1. Newer librarians involved in a promotion and tenure process might be more likely to become involved in managing open access repositories.

2. Newer librarians, fresh out of graduate school, may have had courses that introduced innovative technologies such as open access repositories, resulting in a stronger proclivity to take on these projects.

The first hypothesis was not supported by this survey's results. In fact, 81 percent (26 out of 31) of respondents involved in open access repositories and 76 percent (26 out of 34 ) of respondents involved in open access journals were in positions that did not even require that they obtain tenure. Overall, only 34 percent (88 out of 261) of all respondents were in positions that required tenure attainment. The second hypothesis cannot be addressed with current data but is an interesting question for future studies.

\section{TABLE 4}

\section{Level of Support for Concepts Related to Open Access}

\begin{tabular}{|c|l|}
\hline \hline $\begin{array}{l}\text { Percentage (number) of respondents } \\
\text { who agreed or strongly agreed with } \\
\text { the accompanying statement }\end{array}$ & Statement \\
\hline $77 \%(202)$ & $\begin{array}{l}\text { The principles of open access relate to the } \\
\text { purpose of academic libraries. }\end{array}$ \\
\hline $81 \%(213)$ & $\begin{array}{l}\text { Involvement in open access initiatives is one } \\
\text { way for academic libraries to stay relevant in a } \\
\text { changing information landscape. }\end{array}$ \\
\hline $46 \%(121)$ & $\begin{array}{l}\text { Open access will fail without the active } \\
\text { involvement of academic libraries. }\end{array}$ \\
\hline
\end{tabular}


Gender had no bearing on attitude scores or involvement in management of open access projects. Not surprisingly, there is a relationship between an institution's highest degree offered and institutional involvement in open access projects, with Ph.D.-granting institutions being more likely to be involved in managing open access projects.

\section{Exploratory Analysis and Discussion}

It is important to note that open access behaviors are discussed in the following exploratory analysis in two ways:
1. Behaviors that respondents believe librarians and libraries should be exhibiting (that is, behaviors supported in concept); and 2. Behaviors that librarians or libraries are exhibiting (that is, behaviors actually performed).

\section{Behaviors Supported in Concept}

That librarians support the basic principles of open access is not a surprise. (See table 4.) Yet respondents are not as sure of libraries' roles in this process, with under half $(46 \%)$ of respondents agreeing or strongly agreeing that open access will

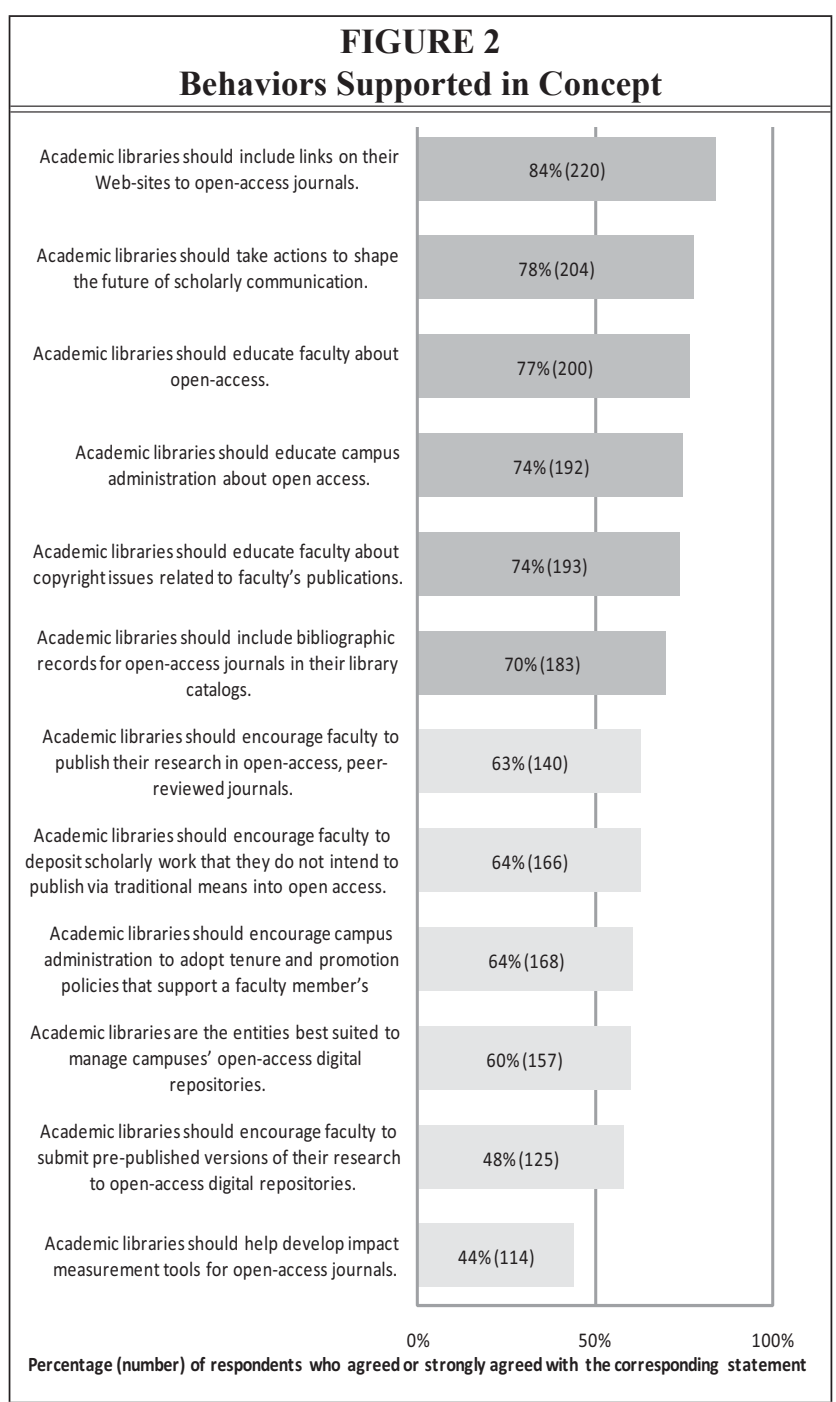

"fail without the active involvement of libraries." Figure 2 provides insight into the level of librarian support of specific types of open access-related behaviors. While librarians support every behavior listed in figure 2, there is a decline in support when statements move from activities traditionally held by librarians (darker bars) to activities not typically associated with librarian work (lighter bars). Libraries have long been involved in educating campus constituents about scholarly resources, as well as organizing and creating access to these resources via tools such as the catalog. Developing impact measurement tools, encouraging faculty to publish, and affecting faculty tenure and promotion processes, however, push the boundaries of traditional library work. 


\begin{tabular}{|c|l|}
\hline \multicolumn{2}{|c|}{ TABLE 5 } \\
Behaviors Requiring Personnel/Fund Commitments \\
\hline $\begin{array}{l}\text { Percentage (number) of respondents } \\
\text { who agreed or strongly agreed with } \\
\text { the accompanying statement }\end{array}$ & Statement \\
\hline $30 \%(80)$ & $\begin{array}{l}\text { Academic libraries should create professional } \\
\text { positions whose main duties concern open } \\
\text { access issues and projects. }\end{array}$ \\
\hline $34 \%(89)$ & $\begin{array}{l}\text { Academic libraries should seek external funding } \\
\text { to finance open access projects. }\end{array}$ \\
\hline $21 \%(55)$ & $\begin{array}{l}\text { Providing financial resources to support open } \\
\text { access should be a priority of academic libraries } \\
\text { at this point. }\end{array}$ \\
\hline $13 \%(33)$ & $\begin{array}{l}\text { Academic libraries should reallocate existing } \\
\text { resources to support the development of open } \\
\text { access projects. }\end{array}$ \\
\hline
\end{tabular}

Another important finding of this study is that the high level of support for open access behaviors drops dramatically for behaviors that expressly include a commitment of personnel and/or funds. Only 34 percent (89) of respondents agreed or strongly agreed that libraries should seek external funding to finance open access projects, and only 13 percent (33) agreed or strongly agreed that libraries should seek funding through internal library fund reallocation. (See table 5.)

Another question that touches on financial support of open access by libraries measures respondents' agreement with the following: "academic libraries should create professional positions whose main duties concern open access issues and projects," such as the one advertised by the University of Michigan via Libraries Association JobList. The position reads in part, "The University Library seeks an Associate University Librarian for Scholarly Resources ... to be a national leader in this discussion and to advance scholarly communication issues such as copyright, scholarly publication pricing, alternative publishing models, institutional repositories, and open access." ${ }^{24}$ Only 30 percent (80) of respondents agreed or strongly agreed that libraries should be creating professional positions whose main duties concern open access issues and projects, and 49 percent (128) of the respondents had no opinion or only somewhat agreed. While this survey did not ask the respondents if their institution housed such a position, the ARL SPEC Kit 299: Scholarly Communication Education Initiatives survey revealed some instances of library positions with scholarly communication education responsibilities (of which open access is a piece). "Twentyone respondents (32\%) identified a Chief [Scholarly Communications] Librarian who has primary responsibility for education initiatives. About half of these are at the Assistant/Associate Librarian level. Only three of these librarians (14\%) devote $100 \%$ of their time to [Scholarly Communication] initiatives. Most of the chief [Scholarly Communication] librarians have split appointments and all but a few devote less than $30 \%$ of their time to this work." 25

Funding is raised in another survey deployed in 2005 by CNI, the UK Joint Information Systems Committee, and the SURF Foundation, in preparation for the international conference "Making the Strategic Case for Institutional Repositories." Gerard van Westrienen and Clifford A. Lynch's report of this survey finds that one commonly stated inhibitor 
for establishing, filling, and maintaining institutional repositories was resource constraints. ${ }^{26}$ In another article, Bailey recognizes that librarians may actually be more likely to be resistant to repositories than other open access advocates because of cost: "Open access advocates may focus on technical support costs of [institutional repositories], while librarians may also be concerned with additional costs, such as staff and user training and support, [institutional repository] advocacy and promotion, metadata creation and maintenance (including depositing items for busy faculty), and long-term digital preservation. Consequently, some open access advocates can see [institutional repositories] as cheap to support and quick to implement, while librarians can take a more cautious approach that takes into consideration other costs and the library maxim that it is easier to establish a new service than to stop offering one." ${ }^{27}$

Another potential cost for libraries is the payment of author-side open access publishing fees. Though no-fee open access publishing models abound (see the 2005 survey from the Kaufman-Willis Group), ${ }^{28}$ Yale University's cancellation of their BioMed Central membership, an open access journal publisher that requires financial support from submitting entities such as the author or author's institutional library, speaks to the reality of potential open access costs for libraries. From the SciLib Weblog posting announcing Yale Library's decision, "The costs have proved unsustainable... Starting with 2005, BioMed Central article charges cost the libraries $\$ 4,658$, comparable to a single biomedicine journal subscription. The cost of article charges for 2006 then jumped to $\$ 31,625$. The article charges have continued to soar in 2007 with the libraries charged $\$ 29,635$ through June 2007 , with $\$ 34,965$ in potential additional article charges in submission." 29

Perhaps librarians are right to be hesitant in regard to funding open access. Alternatively, David Lewis, in "A Strategy for Academic Libraries in the First Quarter of the 21st Century," suggests another alternative: "The transition from print to electronic resources should provide staff savings as the number of individual print items selected, processed, and managed decreases and more comprehensive electronic resources are acquired. These savings should be both professional and clerical. It will be important to capture and redeploy these resources. In addition, there should be savings in the costs of binding, postage, and cataloging fees." ${ }^{30}$ This outlook proposes that open access or

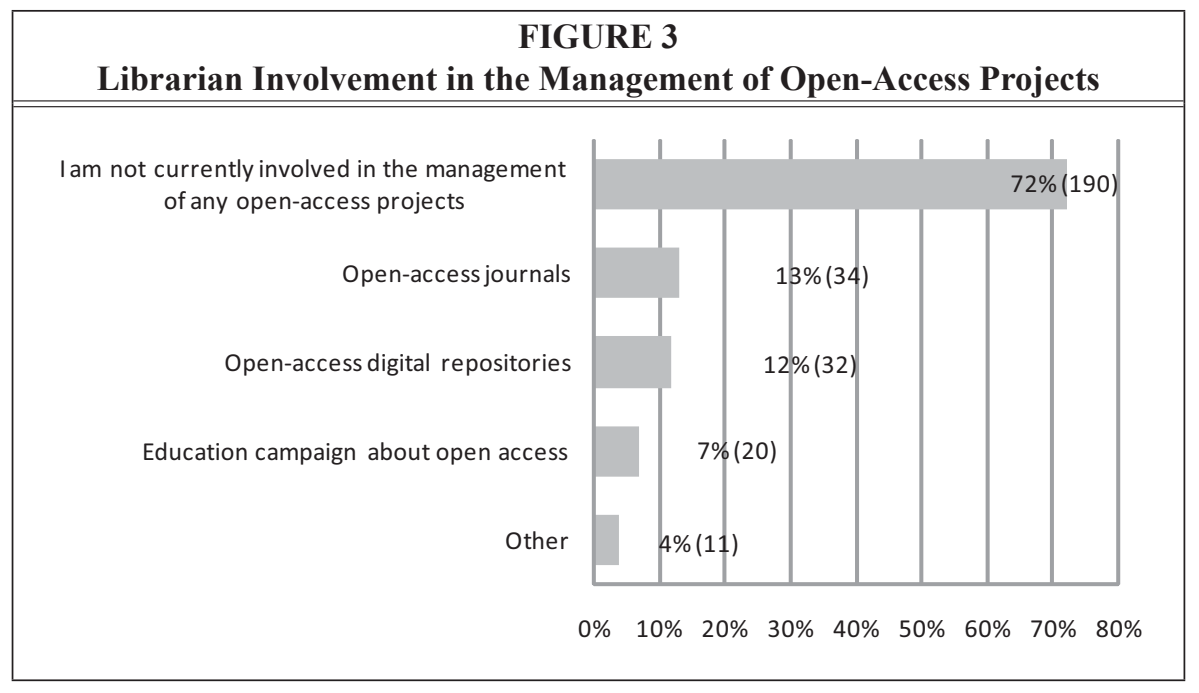


more broadly the transition from print to electronic resources may eventually be absorbed by the repositioning of traditional library activities such as, but not necessarily limited to, cataloging, acquisitions, and collection development.

\section{Behaviors Performed}

One of the primary findings of this survey is the discrepancy between librarian support of open access concepts and actions taken that reflect this stated support. Respondents believe their profession should be a part of at least some aspects of the open access movement, but few are currently taking any action toward this end. Noteworthy is the discrepancy between the levels of support respondents purport for library involvement in educating others about open access and actual education behaviors performed. While all concepts related to education were agreed to or strongly agreed to at a level of 70 percent or higher (see figure 2,) only 20 percent (54) of respondents' institutions and 7 percent (20) of respondents were involved in education campaigns relating to open access. (See figure 3.)

Respondents also reported low levels of involvement in less formal means of education such as conversing with others about open access. (See figure 4.) Over half of the respondents reported never having spoken with nonlibrary academic faculty about open access. The 2006 survey of University of California faculty regarding changes in scholarly communication indicates university faculty are not being educated (be it by librarians, themselves, or others) about open access content in institutional repositories. “While faculty evidence interest in learning about new scholarship and dissemination activities occurring across the scholarly community, their awareness of alternative scholarly communication opportunities is generally low... Among all faculty respondents, $82 \%$ said that they are 'not aware of' or 'aware of but don't know much' about institutionally-based repositories of open access content." 31 The presently reported survey indicates that librarians are more active at interprofessional communication on the topic, with over 50 percent reporting open access-related communications with other librarians both on and off their own campus, several times a year.

Librarian attitudes, as they relate to reported position types, may help open access advocates better target their librarian-focused promotion efforts. Respondents who reported their main job description as Acquisitions had lower attitude scores than all other listed position types (see question 33 in Appendix A for position type categories), while Public Services stood out with less positive attitudes than those in Cataloging, Collection Development, Digital Libraries, and Subject Specialists. It is important to note that respondents were only allowed to select one position type, and the Reference was a category of choice separate from Public Services. Reference librarians did not have lower attitude scores. Data from this survey are not sufficient to address why Acquisitions and Public Service librarians feel this way, but one might again consider Lewis' article. Do

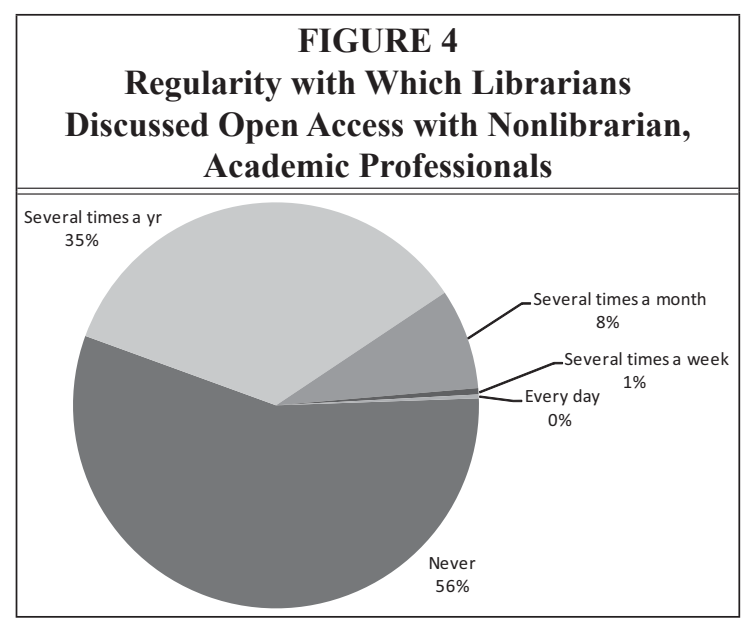


Acquisitions librarians fear the loss or dramatic change in job description as a result of fewer purchased library materials? This demographic information offers open access advocates several avenues for continuing promotional efforts:

1. Focus internal library education efforts on Public Services and Acquisitions librarians highlighting the open access benefits that would be of most interest to them.

2. Work with librarians who already have more positive attitudes toward open access, as they will be most likely to support promotional efforts external to the library.

3. Talk with Public Services and Acquisitions librarians to determine the nature of their hesitancy toward open access. These individuals may be aware of specific issues that many open access promoters have not yet considered.

\section{Conclusion and Future Studies}

This study indicates that librarians support the concepts of open access and, more important, believe that that these concepts are related to their work as librarians. The University of California survey indicates that nonlibrary faculty are invested in librarian participation in the evolution of scholarly communication: "Among all faculty respondents, Scholarship/Office of Scholarly Communications Campus library/librarians placed second, with $43 \%$ of respondents selecting it within their top three choices out of ten as the most effective source for keeping faculty updated about UC eScholarship services." 32 University administrators are also voicing the necessity of library involvement, evidenced by the 132 university leaders who declared their support of the United States Senate Bill 2695, also called the Federal Research Public Access Act of 2006. ${ }^{33}$ In 2006, the "Open Letter to the Higher Education Community," regarding the Federal Research Public Access Act of 2006, was signed by 22 University Provosts, including those of Northwestern, Harvard,
Indiana University, and University of California. This letter expressed support of mandated open, public access to federally funded research and also specifically recognized academic libraries' role in this process. "Scholarly publishers, academic libraries, university leaders, and scholars themselves must engage in an ongoing dialogue about the means of scholarly production and distribution." ${ }^{34}$

Librarians are in favor of seeing their profession take some actions toward open access. The most highly supported behaviors were those that extend traditional library activities such as educating faculty about open access and providing a means by which to locate open access items. Indeed, involvement in education campaigns was not only highly supported, but those librarians managing education campaigns also had significantly more supportive attitudes than other respondents. This positive connection offers open access proponents a logical avenue for focusing their efforts. Yet this survey found that agreement with various open access-related concepts does not constitute actual action. Bailey states in "Open Access and Libraries" that "Action does not require total agreement with the open access movement's beliefs and proposals." 35 Perhaps this need for agreement is greater than anticipated and may be influencing action. Librarians are not alone in this discrepancy between attitude and performed behavior. Again from the University of California faculty survey, "The UC faculty largely conform to conventional behavior regarding scholarly communication, such as publishing in traditional venues, but widely express a need for change in the current systems of scholarly communication. In fact $47 \%$ University of California faculty respondents indicated that they were in favor of a proposal to routinely grant to the University a limited, non-exclusive license to place their scholarly publications in a non-commercial, publicly accessible online repository."36

This survey's results indicate that funding may be one of the primary reasons for little present action from librarians. While 
the survey results do not shed light on what library monies are actually being spent in support of open access initiatives, they indicate a low level of willingness to expend such funds. In line with Lynch and Lippincott's analysis of the CNI survey, answering questions related to funding open access projects will be "crucial in moving forward... particularly as institutions move beyond the one-time arrangements such as grants or special allocations that are often being used to help fund development and start-up costs." ${ }^{\prime 37}$
While this survey answered important questions about the level of support by librarians in concept and in action toward open access's goals, it also raised questions for future studies such as: How are current library-managed open access projects being funded? If funding were not an issue, would librarians be more willing to manage and promote open access projects? What other entities, institutions, groups, or professions need to be involved in advocating open access's principles?

\section{Notes}

1. Jean-Claude Guédon, In Oldenburg's Long Shadow: Librarians, Research Scientists, Publishers, and the Control of Scientific Publishing (Annapolis Junction, Md.: ARL, 2001). Available online at www.arl.org/resources/pubs/mmproceedings/138guedon.shtml. [Accessed 22 May 2008].

2. Peter Suber, "Timeline of Open Access Movement." Available online at www.earlham. edu/ peters/fos/timeline.htm. [Accessed 30 November 2007].

3. Open Access Now, "Summary of the April 11, 2003, Meeting on Open Access Publishing." Available online at www.biomedcentral.com/openaccess/bethesda/\#definition. [Accessed 22 May 2008].

4. Conference on Open Access to Knowledge in the Sciences and Humanities, "Berlin Declaration on Open Access to Knowledge in the Sciences and Humanities." Available online at http:// oa.mpg.de/openaccess-berlin/berlindeclaration.html. [Accessed 22 May 2008].

5. "Budapest Open Access Initiative." Available online at www.soros.org/openaccess/read. shtml. [Accessed 22 May 2008].

6. Nancy Fried Foster and Susan Gibbons, "Understanding Faculty to Improve Content Recruitment for Institutional Repositories," D-Lib Magazine 11, no. 1 (Jan. 2005). Available online at www.dlib.org/dlib/january05/foster/01foster.html. [Accessed 30 November 2007].

7. Stevan Harnard, "Green OA Self-Archiving Needs a Lobbying Organisation." Available online at http://eprints.ecs.soton.ac.uk/13966/1/arch-lobby.html. [Accessed 2 June 2008].

8. Krista D. Schmidt, Pongracz Sennyey, and Timothy V. Carstens, "New Roles for a Changing Environment: Implications of Open Access for Libraries," College \& Research Libraries 66, no. 5 (Sept. 2005): 407-16. $18-24$.

9. Sara Fine, "Change and Resistance: The Cost/Benefit Factor," The Bottom Line 5, no. 1 (1991):

10. ACRL Press Release, "ACRL Begins Scholarly Communication Initiative," (2002). Available online at

www.ala.org/ala/pressreleasesbucket/acrlbeginsscholarly.htm [Accessed 30 Nov. 2007].

11. Charles W. Bailey, Jr., "Scholarly Electronic Publishing Bibliography: 2006 Annual Edition," (2007). Available online at www.digital-scholarship.org/sepb/annual/sepb2006.pdf. [Accessed 3 December 2007]. 351-83.

12. Charles W. Bailey, Jr., “Open Access and Libraries,” Collection Management 32, no. 3/4 (2007):

13. Suzie Allard, Thura R. Mack, and Melanie Feltner-Reichert, “The Librarian's Role in Institutional Repositories: A Content Analysis of the Literature," Reference Services Review 33, no. 3 (2005): 325-36.

14. Clifford A. Lynch and Joan K. Lippincott, "Institutional Repository Deployment in the United States as of Early 2005," D-Lib Magazine 11, no. 9 (Sept. 2005). Available online at www. dlib.org/dlib/september05/lynch/09lynch.html. [Accessed 30 November 2007].

15. Alma Swan and Sheridan Brown (Key Perspectives), "JISC/OSI Journal Authors Survey Report" (Mar. 2004). Available online at www.jisc.ac.uk/uploaded_documents/JISCopen accessreport1.pdf. [Accessed 3 December 2007].

16. Howard Carter, Carolyn A. Snyder, and Andrea Imre, "Library Faculty Publishing and Intellectual Property Issues: A Survey of Attitudes and Awareness," portal: Libraries and the Academy 7, no. 1 (2007): 65-79. 
17. Kathleen A. Newman, Deborah D. Blecic, and Kimberly L. Armstrong, SPEC Kit 299: Scholarly Communication Education Initiatives (Washington, D.C.: Association of College and Research Libraries, 2007). Available online at http://hdl.handle.net/2142/2458. [Accessed 2 June 2008].

18. Leslie Carr and Stevan Harnard, "Keystroke Economy: A Study of the Time and Effort Involved in Self-Archiving" (March 2005). Available online at http://eprints.ecs.soton.ac.uk/10688/1/ KeystrokeCosting-publicdraft1.pdf. [Accessed 30 November 2007].

19. The University of California Office of Scholarly Communication and the California Digital Library eScholarship Program, "Faculty Attitudes and Behaviors Regarding Scholarly Communication: Survey Findings from the University of California" (Aug. 2007). Available online at http:// osc.universityofcalifornia.edu/responses/materials/OSC-survey-full-20070828.pdf. [Accessed 3 December 2007].

20. "Large Majorities of U.S. Adult Support Easy and Free Online Access to Federally-Funded Research Findings on Health Issues and Other Topics," Harris Poll 44 (May 2006). Available online at www.harrisinteractive.com/harris_poll/index.asp?PID=671. [Accessed 13 May 2008].

21. National Center for Education Statistics, "Documentation for the Academic Library Survey (ALS) Data File: Fiscal Year 2002" (Dec. 2002). Available online at http://nces.ed.gov/pubsearch/ pubsinfo.asp?pubid=2006308. [Accessed 13 May 2008].

22. Robert V. Krejcie and Daryle W. Morgan, "Determining Sample Size for Research Activities," Educational and Psychological Measurement 30 (1970): 607-10.

23. It is important to note that, because the open access survey was completely confidential, it is impossible to list the respondents by their institution's NCES-ALS highest-degree-granted category. Instead, one is offered a sense of the types of institutions to which respondents belong through self-reporting from open access survey Question 34, which asked respondents to "indicate the highest degree granted by your institution."

24. Job posting, www.joblist.ala.org (Posted June 22, 2007). [Accessed 15 August 2007].

25. Newman, Blecic, and Armstrong, SPEC Kit 299, 11.

26. Gerard van Westrienen and Clifford A. Lynch, "Academic Institutional Repositories Deployment Status in 13 Nations as of Mid 2005," D-Lib Magazine 11, no. 9 (Sept. 2005). Available online at www.dlib.org/dlib/september05/westrienen/09westrienen.html. [Accessed 30 November 2007].

27. Charles W. Bailey, Jr., "The Role of Reference Librarians in Institutional Repositories," Reference Services Review 33, no. 3 (2005): 259-67.

28. Kaufman-Wills Group, "The Facts about Open Access: A Study of Financial and Nonfinancial Effects of Alternative Business Models for Scholarly Journals" (Oct. 24, 2005). Available online at www.alpsp.org/ForceDownload.asp?id=70. [Accessed 13 October 2008].

29. Ann Okerson, R. Kenny Marone, and David Stern, "Library Drops BioMed Central's Open Access Membership," SciLib-Weblog (Aug. 3, 2007). Available online at www2.library.yale.edu/ movabletype/scilib/archive/2007/08/library_drops_b_1.html. [Accessed 30 November 2007].

30. David W. Lewis, "A Strategy for Academic Libraries in the First Quarter of the 21st Century," College $\mathcal{E}$ Research Libraries 68, no. 5 (Sept. 2007): 418-34. Available online at http://hdl.handle. net/1805/953. [Accessed 30 November 2007].

31. The University of California, "Faculty Attitudes and Behaviors Regarding Scholarly Communication: Survey Findings from the University of California," 72.

32. Ibid., 101.

33. SPARC, "Higher Ed Leaders Support Public Access" (Jan. 8, 2007) Available online at www. arl.org/sparc/advocacy/frpaa/institutions.shtml. [Accessed 8 October 2008].

34. Susan D. Allen, et al., "An Open Letter to the Higher Education Community" (July 24, 2006). Available online at www.cic.uiuc.edu/groups/CICMembers/archive/documents/FRPAAletterFinal7-24-06.pdf. [Accessed 13 May 2008].

35. Bailey, “Open Access and Libraries," 378.

36. The University of California, "Faculty Attitudes and Behaviors Regarding Scholarly Communication: Survey Findings from the University of California," 6.

37. Lynch and Lippincott, "Institutional Repository Deployment in the United States as of Early 2005." 


\section{Appendix A: Text, But Not Format, of the Survey Instrument}

\section{Open Access and Academic Libraries Introduction}

The promotion of open access and development of open access projects have become prominent initiatives in many academic libraries. It is unclear, however, how librarians feel about their involvement in these initiatives. The goal of this survey is to find out how academic librarians feel about their personal involvement and the involvement of academic libraries in open access initiatives.

\section{Definitions}

Please use the following definitions of open access, scholarly communication, and digital repositories for the purpose of this survey.

Open access: Scholarship that is available online free of charge.

Scholarly communication: The process by which scholars disseminate their intellectual output, including but not limited to scholarly articles.

Digital repositories: Online collections that capture, preserve, and allow access to the intellectual output of a specified group of scholars.

There are no right or wrong answers. Please answer honestly; your answers will remain anonymous.

\section{Part I:}

The following series of statements pertains to your personal opinions about academic libraries' involvement in scholarly communication and open access issues.

- Please read each statement and indicate your opinion by selecting a number in the range that best corresponds with your opinion.

- Marking 1 indicates you Strongly disagree with the statement while marking 7 indicates you Strongly agree with the statement.

1. Academic libraries should take actions to shape the future of scholarly communication.

$\begin{array}{ccccccc}\begin{array}{c}\text { Strongly } \\ \text { Disagree }\end{array} & \text { Disagree } & \begin{array}{c}\text { Somewhat } \\ \text { disagree }\end{array} & \begin{array}{c}\text { No } \\ \text { opinion }\end{array} & \begin{array}{c}\text { Somewhat } \\ \text { agree }\end{array} & \text { Agree } & \begin{array}{c}\text { Strongly } \\ \text { agree }\end{array} \\ 1 & 2 & 3 & 4 & 5 & 6 & 7\end{array}$

2. Open access will fail without the active involvement of academic libraries.

$\begin{array}{ccccccc}\begin{array}{c}\text { Strongly } \\ \text { Disagree }\end{array} & \text { Disagree } & \begin{array}{c}\text { Somewhat } \\ \text { disagree }\end{array} & \begin{array}{c}\text { No } \\ \text { opinion }\end{array} & \begin{array}{c}\text { Somewhat } \\ \text { agree }\end{array} & \text { Agree } & \begin{array}{c}\text { Strongly } \\ \text { agree }\end{array} \\ 1 & 2 & 3 & 4 & 5 & 6 & 7\end{array}$

3. The principles of open access relate to the purpose of academic libraries.

$\begin{array}{ccccccc}\begin{array}{c}\text { Strongly } \\ \text { Disagree }\end{array} & \text { Disagree } & \begin{array}{c}\text { Somewhat } \\ \text { disagree }\end{array} & \begin{array}{c}\text { No } \\ \text { opinion }\end{array} & \begin{array}{c}\text { Somewhat } \\ \text { agree }\end{array} & \text { Agree } & \begin{array}{c}\text { Strongly } \\ \text { agree }\end{array} \\ 1 & 2 & 3 & 4 & 5 & 6 & 7\end{array}$

4. Involvement in open access initiatives is one way for academic libraries to stay relevant in a changing information landscape.

$\begin{array}{ccccccc}\begin{array}{c}\text { Strongly } \\ \text { Disagree }\end{array} & \text { Disagree } & \begin{array}{c}\text { Somewhat } \\ \text { disagree }\end{array} & \begin{array}{c}\text { No } \\ \text { opinion }\end{array} & \begin{array}{c}\text { Somewhat } \\ \text { agree }\end{array} & \begin{array}{c}\text { Agree } \\ \text { agree }\end{array} \\ 1 & 2 & 3 & 4 & 5 & 6 & 7\end{array}$


5. Academic libraries should educate faculty about open access.

$\begin{array}{ccccccc}\begin{array}{c}\text { Strongly } \\ \text { Disagree }\end{array} & \text { Disagree } & \begin{array}{c}\text { Somewhat } \\ \text { disagree }\end{array} & \begin{array}{c}\text { No } \\ \text { opinion }\end{array} & \begin{array}{c}\text { Somewhat } \\ \text { agree }\end{array} & \begin{array}{c}\text { Agree } \\ \text { Strongly } \\ \text { agree }\end{array} \\ 1 & 2 & 3 & 4 & 5 & 6 & 7\end{array}$

6. Academic libraries should educate campus administration about open access.

$\begin{array}{ccccccc}\begin{array}{c}\text { Strongly } \\ \text { Disagree }\end{array} & \text { Disagree } & \begin{array}{c}\text { Somewhat } \\ \text { disagree }\end{array} & \begin{array}{c}\text { No } \\ \text { opinion }\end{array} & \begin{array}{c}\text { Somewhat } \\ \text { agree }\end{array} & \text { Agree } & \begin{array}{c}\text { Strongly } \\ \text { agree }\end{array} \\ 1 & 2 & 3 & 4 & 5 & 6 & 7\end{array}$

7. Academic libraries should educate faculty about copyright issues related to the faculty's publications.

$\begin{array}{ccccccc}\begin{array}{c}\text { Strongly } \\ \text { Disagree }\end{array} & \text { Disagree } & \begin{array}{c}\text { Somewhat } \\ \text { disagree }\end{array} & \begin{array}{c}\text { No } \\ \text { opinion }\end{array} & \begin{array}{c}\text { Somewhat } \\ \text { agree }\end{array} & \text { Agree } & \begin{array}{c}\text { Strongly } \\ \text { agree }\end{array} \\ 1 & 2 & 3 & 4 & 5 & 6 & 7\end{array}$

8. Academic libraries should encourage faculty to submit prepublished versions of their research to open access digital repositories.

$\begin{array}{ccccccc}\begin{array}{c}\text { Strongly } \\ \text { Disagree }\end{array} & \text { Disagree } & \begin{array}{c}\text { Somewhat } \\ \text { disagree }\end{array} & \begin{array}{c}\text { No } \\ \text { opinion }\end{array} & \begin{array}{c}\text { Somewhat } \\ \text { agree }\end{array} & \text { Agree } & \begin{array}{c}\text { Strongly } \\ \text { agree }\end{array} \\ 1 & 2 & 3 & 4 & 5 & 6 & 7\end{array}$

9. Academic libraries should encourage faculty to publish their research in open access, peer-reviewed journals.

$\begin{array}{ccccccc}\begin{array}{c}\text { Strongly } \\ \text { Disagree }\end{array} & \text { Disagree } & \begin{array}{c}\text { Somewhat } \\ \text { disagree }\end{array} & \begin{array}{c}\text { No } \\ \text { opinion }\end{array} & \begin{array}{c}\text { Somewhat } \\ \text { agree }\end{array} & \text { Agree } & \begin{array}{c}\text { Strongly } \\ \text { agree }\end{array} \\ 1 & 2 & 3 & 4 & 5 & 6 & 7\end{array}$

10. Academic libraries should encourage faculty to deposit scholarly work that they do not intend to publish via traditional means (such as white papers, datasets, or multimedia presentations) into open access digital repositories.

$\begin{array}{ccccccc}\begin{array}{c}\text { Strongly } \\ \text { Disagree }\end{array} & \text { Disagree } & \begin{array}{c}\text { Somewhat } \\ \text { disagree }\end{array} & \begin{array}{c}\text { No } \\ \text { opinion }\end{array} & \begin{array}{c}\text { Somewhat } \\ \text { agree }\end{array} & \text { Agree } & \begin{array}{c}\text { Strongly } \\ \text { agree }\end{array} \\ 1 & 2 & 3 & 4 & 5 & 6 & 7\end{array}$

11. Academic libraries should encourage campus administration to adopt tenure and promotion policies that support a faculty member's decision to publish in open access journals.

$\begin{array}{ccccccc}\begin{array}{c}\text { Strongly } \\ \text { Disagree }\end{array} & \text { Disagree } & \begin{array}{c}\text { Somewhat } \\ \text { disagree }\end{array} & \begin{array}{c}\text { No } \\ \text { opinion }\end{array} & \begin{array}{c}\text { Somewhat } \\ \text { agree }\end{array} & \text { Agree } & \begin{array}{c}\text { Strongly } \\ \text { agree }\end{array} \\ 1 & 2 & 3 & 4 & 5 & 6 & 7\end{array}$

12. Academic libraries should include bibliographic records for open access journals in their library catalogs.

$\begin{array}{ccccccc}\begin{array}{c}\text { Strongly } \\ \text { Disagree }\end{array} & \text { Disagree } & \begin{array}{c}\text { Somewhat } \\ \text { disagree }\end{array} & \begin{array}{c}\text { No } \\ \text { opinion }\end{array} & \begin{array}{c}\text { Somewhat } \\ \text { agree }\end{array} & \text { Agree } & \begin{array}{c}\text { Strongly } \\ \text { agree }\end{array} \\ 1 & 2 & 3 & 4 & 5 & 6 & 7\end{array}$


13. Academic library Web sites should include links to open access journals.

$\begin{array}{ccccccc}\begin{array}{c}\text { Strongly } \\ \text { Disagree }\end{array} & \text { Disagree } & \begin{array}{c}\text { Somewhat } \\ \text { disagree }\end{array} & \begin{array}{c}\text { No } \\ \text { opinion }\end{array} & \begin{array}{c}\text { Somewhat } \\ \text { agree }\end{array} & \text { Agree } & \begin{array}{c}\text { Strongly } \\ \text { agree }\end{array} \\ 1 & 2 & 3 & 4 & 5 & 6 & 7\end{array}$

14. Academic libraries should create professional positions whose main duties concern open access issues and projects.

$\begin{array}{ccccccc}\begin{array}{c}\text { Strongly } \\ \text { Disagree }\end{array} & \text { Disagree } & \begin{array}{c}\text { Somewhat } \\ \text { disagree }\end{array} & \begin{array}{c}\text { No } \\ \text { opinion }\end{array} & \begin{array}{c}\text { Somewhat } \\ \text { agree }\end{array} & \text { Agree } & \begin{array}{c}\text { Strongly } \\ \text { agree }\end{array} \\ 1 & 2 & 3 & 4 & 5 & 6 & 7\end{array}$

15. Academic libraries are the entities best suited to manage campuses' open access digital repositories.

$\begin{array}{ccccccc}\begin{array}{c}\text { Strongly } \\ \text { Disagree }\end{array} & \text { Disagree } & \begin{array}{c}\text { Somewhat } \\ \text { disagree }\end{array} & \begin{array}{c}\text { No } \\ \text { opinion }\end{array} & \begin{array}{c}\text { Somewhat } \\ \text { agree }\end{array} & \text { Agree } & \begin{array}{c}\text { Strongly } \\ \text { agree }\end{array} \\ 1 & 2 & 3 & 4 & 5 & 6 & 7\end{array}$

16. Academic libraries should replace exorbitantly priced journals with comparable open access journals when available.

$\begin{array}{ccccccc}\begin{array}{c}\text { Strongly } \\ \text { Disagree }\end{array} & \text { Disagree } & \begin{array}{c}\text { Somewhat } \\ \text { disagree }\end{array} & \begin{array}{c}\text { No } \\ \text { opinion }\end{array} & \begin{array}{c}\text { Somewhat } \\ \text { agree }\end{array} & \begin{array}{c}\text { Agree } \\ \text { Strongly } \\ \text { agree }\end{array} \\ 1 & 2 & 3 & 4 & 5 & 6 & 7\end{array}$

17. Academic libraries should give subscription preference to journal publishers who allow authors to retain copyright.

$\begin{array}{ccccccc}\begin{array}{c}\text { Strongly } \\ \text { Disagree }\end{array} & \text { Disagree } & \begin{array}{c}\text { Somewhat } \\ \text { disagree }\end{array} & \begin{array}{c}\text { No } \\ \text { opinion }\end{array} & \begin{array}{c}\text { Somewhat } \\ \text { agree }\end{array} & \text { Agree } & \begin{array}{c}\text { Strongly } \\ \text { agree }\end{array} \\ 1 & 2 & 3 & 4 & 5 & 6 & 7\end{array}$

18. Academic libraries should help develop impact measurement tools (such as journal impact factors) for open access journals.

$\begin{array}{ccccccc}\begin{array}{c}\text { Strongly } \\ \text { Disagree }\end{array} & \text { Disagree } & \begin{array}{c}\text { Somewhat } \\ \text { disagree }\end{array} & \begin{array}{c}\text { No } \\ \text { opinion }\end{array} & \begin{array}{c}\text { Somewhat } \\ \text { agree }\end{array} & \text { Agree } & \begin{array}{c}\text { Strongly } \\ \text { agree }\end{array} \\ 1 & 2 & 3 & 4 & 5 & 6 & 7\end{array}$

19. Academic libraries should seek external funding to finance open access projects.

$\begin{array}{ccccccc}\begin{array}{c}\text { Strongly } \\ \text { Disagree }\end{array} & \text { Disagree } & \begin{array}{c}\text { Somewhat } \\ \text { disagree }\end{array} & \begin{array}{c}\text { No } \\ \text { opinion }\end{array} & \begin{array}{c}\text { Somewhat } \\ \text { agree }\end{array} & \text { Agree } & \begin{array}{c}\text { Strongly } \\ \text { agree }\end{array} \\ 1 & 2 & 3 & 4 & 5 & 6 & 7\end{array}$

20. Providing financial resources to support open access should be a priority of academic libraries at this point.

$\begin{array}{ccccccc}\begin{array}{c}\text { Strongly } \\ \text { Disagree }\end{array} & \text { Disagree } & \begin{array}{c}\text { Somewhat } \\ \text { disagree }\end{array} & \begin{array}{c}\text { No } \\ \text { opinion }\end{array} & \begin{array}{c}\text { Somewhat } \\ \text { agree }\end{array} & \text { Agree } & \begin{array}{c}\text { Strongly } \\ \text { agree }\end{array} \\ 1 & 2 & 3 & 4 & 5 & 6 & 7\end{array}$

21. Academic libraries should reallocate existing resources to support the development of open access projects.

$\begin{array}{ccccccc}\begin{array}{c}\text { Strongly } \\ \text { Disagree }\end{array} & \text { Disagree } & \begin{array}{c}\text { Somewhat } \\ \text { disagree }\end{array} & \begin{array}{c}\text { No } \\ \text { opinion }\end{array} & \begin{array}{c}\text { Somewhat } \\ \text { agree }\end{array} & \text { Agree } & \begin{array}{c}\text { Strongly } \\ \text { agree }\end{array} \\ 1 & 2 & 3 & 4 & 5 & 6 & 7\end{array}$




\section{Part II:}

The following series of statements pertains to how often you engage in certain behaviors related to open access.

- Please read each statement and select the number in the range that best corresponds with how frequently you engage in the stated behavior.

- Marking 1 indicates you Never engage in the stated behavior while marking 5 indicates you engage in the stated behavior Every day.

22. On average I monitor listservs, Web sites, and/or blogs that discuss open access.

$\begin{array}{ccccc}\text { Never } & \begin{array}{c}\text { Several times a } \\ \text { year }\end{array} & \begin{array}{c}\text { Several times a } \\ \text { month }\end{array} & \begin{array}{c}\text { Several times a } \\ \text { week }\end{array} & \text { Everyday } \\ 1 & 2 & 3 & 4 & 5\end{array}$

23. On average I read professional literature that discusses open access.

$\begin{array}{ccccc}\text { Never } & \begin{array}{c}\text { Several times a } \\ \text { year }\end{array} & \begin{array}{c}\text { Several times a } \\ \text { month }\end{array} & \begin{array}{c}\text { Several times a } \\ \text { week }\end{array} & \text { Everyday } \\ 1 & 2 & 3 & 4 & 5\end{array}$

24. On average I discuss open access with librarians at campuses outside my own.

$\begin{array}{ccccc}\text { Never } & \begin{array}{c}\text { Several times a } \\ \text { year }\end{array} & \begin{array}{c}\text { Several times a } \\ \text { month }\end{array} & \begin{array}{c}\text { Several times a } \\ \text { week }\end{array} & \text { Everyday } \\ 1 & 2 & 3 & 4 & 5\end{array}$

25. On average I discuss open access with librarians at my campus.

$\begin{array}{ccccc}\text { Never } & \begin{array}{c}\text { Several times a } \\ \text { year }\end{array} & \begin{array}{c}\text { Several times a } \\ \text { month }\end{array} & \begin{array}{c}\text { Several times a } \\ \text { week }\end{array} & \text { Everyday } \\ 1 & 2 & 3 & 4 & 5\end{array}$

26. On average I discuss open access with nonlibrarian, academic professionals at my campus.

$\begin{array}{ccccc}\text { Never } & \begin{array}{c}\text { Several times a } \\ \text { year }\end{array} & \begin{array}{c}\text { Several times a } \\ \text { month }\end{array} & \begin{array}{c}\text { Several times a } \\ \text { week }\end{array} & \text { Everyday } \\ 1 & 2 & 3 & 4 & 5\end{array}$

27. On average I discuss open access with nonlibrarian, academic professionals at campuses outside my own.

$\begin{array}{ccccc}\text { Never } & \begin{array}{c}\text { Several times a } \\ \text { year }\end{array} & \begin{array}{c}\text { Several times a } \\ \text { month }\end{array} & \begin{array}{c}\text { Several times a } \\ \text { week }\end{array} & \text { Everyday } \\ 1 & 2 & 3 & 4 & 5\end{array}$

28. On average I discuss open access with administrators at my library.

$\begin{array}{ccccc}\text { Never } & \begin{array}{c}\text { Several times a } \\ \text { year }\end{array} & \begin{array}{c}\text { Several times a } \\ \text { month }\end{array} & \begin{array}{c}\text { Several times a } \\ \text { week }\end{array} & \text { Everyday } \\ 1 & 2 & 3 & 4 & 5\end{array}$

29. On average I discuss open access with nonlibrary administrators at my campus.

$\begin{array}{ccccc}\text { Never } & \begin{array}{c}\text { Several times a } \\ \text { year }\end{array} & \begin{array}{c}\text { Several times a } \\ \text { month }\end{array} & \begin{array}{c}\text { Several times a } \\ \text { week }\end{array} & \text { Everyday } \\ 1 & 2 & 3 & 4 & 5\end{array}$




\section{Part III:}

Finally, please answer the following questions about yourself or your institution.

30. I am currently personally involved in the management of the following

o open access projects (please mark all that apply):

o open access digital repositories

o open access journals

o education campaign about open access

o I am not currently involved in the management of any open access projects

o other, please specify

31. To my knowledge, my institution is currently involved in the management of the following open access projects (please mark all that apply):

o digital repositories

o open access journal

o education campaign about open access

o to my knowledge, my institution is not currently involved in the management of any open access projects

o other, please specify

32. I have been a librarian for this many years

33. My primary position type would most resemble one of the following descriptions (please choose only one):

o Government Documents

o Acquisitions/Collection Manager

o Administration

o Archives/Special Collections

o Instructional Services

o Audiovisual/Media Servies

o Interlibrary Loan

Cataloging/Metadata

o Circulation/Access Services

o Collection Development

o Development/Fundraising

o Digital Libraries

o Public Services

o Reference

o Subject Specialist/Liaison

o Systems and Network Services

o Web Development/Coordination

o other, please specify

34. Please indicate the highest degree granted by your institution:

o Doctoral degree

o Master's degree

o Baccalaureate degree

o Associate degree

o other, please specify

35. My age is

36. My gender is:

o female

o male

37. My current position in the library:

o does not require that I attain tenure

o does require that I attain tenure, and I have yet to attain it

$\mathrm{o}$ is as a tenured librarian 